\title{
基于陆海统筹视角的国土空间开发建设适宜性评价 以辽宁省为例
}

\author{
纪学朋,黄贤金, 陈 逸, 王丹阳, 宋娅娅
}

(南京大学地理与海洋科学学院, 南京 210023)

\begin{abstract}
摘要：国土空间开发建设适宜性是优化国土空间开发格局、提升开发质量与效益的科学依据 和基础保障, 对实施区域协调发展战略具有重要意义。遵循城乡融合、陆海统筹原则, 以东北 地区唯一既沿海又沿边省份一一辽宁省为例, 从自然环境、经济社会、海洋功能三个维度构建 适宜性评价指标体系, 综合运用特尔斐法、木桶原理法则、线性加权求和法及多要素空间叠置 分析等方法, 对其国土空间开发建设适宜性进行评价与分析。结果表明: 辽宁省国土空间开发 建设适宜性空间分异明显, 适宜建设区与基本适宜建设区呈明显的中心外围分布格局, 沿沈大 轴线、滨海轴线集聚分布; 不适宜建设区以滨海线为轴带南北对称分布; 基本不适宜建设区以 沈大线为轴带东西对称分布。适宜、基本适宜、基本不适宜、不适宜建设区面积依次为 $15504.39 \mathrm{~km}^{2} 、 22645.34 \mathrm{~km}^{2} 、 66833.96 \mathrm{~km}^{2} 、 68720.99 \mathrm{~km}^{2}$, 分别占陆海国土的 $8.93 \% 、 13.04 \%$ 、 38.48\%、39.56\%。自然环境对区域国土空间开发建设具有基础性、决定性作用,不同等级、不同 区域自然环境适宜性集聚与分散特性差异显著; 经济社会对自然环境的适宜、基本适宜、基本 不适宜建设区修正作用明显。海洋功能区的引人, 极大拓展了辽宁省国土空间范围。但海洋 功能适宜性空间分布极不均衡, 由于海洋国土本身属性, 其可供直接开发建设空间有限, 而保 护空间广阔,国土空间开发建设与生态环境保护之间的矛盾依然严峻。
\end{abstract}

关键词: 国土空间开发; 建设用地; 城乡融合; 陆海统筹;适宜性评价; 辽宁省

人与自然和谐的现代化是美丽中国建设的重要内涵 ${ }^{[1]}$ 。但 “不平衡不充分的发展”问 题在我国国土空间开发过程中尤为突出, 也影响着人与自然的协调发展。集中体现在区 域空间开发失衡、资源环境约束趋紧、城乡发展差距扩大、“三生空间”冲突加剧、陆海 统筹开发缺乏等方面 ${ }^{[2-3]}$ 。土地适宜性评价, 即评定一定条件下一定范围内土地对某种用 途或功能的适宜程度 ${ }^{[4-6]}$, 是缓和甚至解决上述 “不平衡不充分” 矛盾的科学基础。国土 空间开发建设适宜性，是人类社会在 “适地” 到 “适空间” 过程中逐步发展的 ${ }^{[5-8]}$ 。纵观 我国现代土地适宜性评价，历经 1950-1960年代的荒地调查、1970年代土地适宜性评价 体系的建立、1980年代农用地到非农用地评价的转向。从1990年代至今, 随着我国工业 化和城镇化进程的快速推进, 国土空间开发与建设用地适宜性愈发受到包括地理学、土 地科学、城市规划学等领域的关注与重视, 相关学者针对不同评价目标利用多种评价方 法在不同地域开展了丰富的案例研究 ${ }^{[6,9-10]}$ 。从研究方法上看, RS 和 GIS 技术的快速发展

收稿日期：2018-09-01; 修订日期：2018-12-30

基金项目：国家社科基金重大项目（17ZDA061）

作者简介：纪学朋（1991- ), 男, 山东章丘人, 博士研究生, 研究方向为资源环境与可持续发展。 E-mail: zq jixuepeng@163.com

通讯作者：黄贤金（1968-)，男，江苏扬中人，教授，博士生导师，研究方向为资源地理与土地利用。 E-mail: hxj369@nju.edu.cn 
和深度应用, 丰富了评价数据来源, 提高了评价方法的可操作性和评价结果的准确性, 国内外学者运用 “多要素空间叠置分析” [11-14]、“景观格局分析” [15]、“生态位模型” ${ }^{[16] 、}$ “模糊数学” [17]、“神经网络” ${ }^{[18]}$ 等方法对典型地域进行深人研究, 但仍以多要素空间叠 置分析应用最为广泛, 研究方法呈现多元化、集成化、综合化的特点, 因子选择、指标 体系构建也更加贴合国土空间开发建设实践。从研究地域上看, 涵盖城镇 ${ }^{[13,15,19-23]}$ 、乡 村 $^{[16]}$ 、灾区 ${ }^{[24,25]}$ 、山地丘陵 ${ }^{[16,26-28]}$ 、沿江沿海 ${ }^{[29-31]}$ 等地域类型, 并逐渐转向山地丘陵、沿江 沿海等自然环境复杂且生态脆弱地区, 或城乡结合部、城镇密集区等空间冲突剧烈地 区，涉及微观、中观、宏观等多个研究尺度，以及栅格、格网、县市等多种评价单元， 呈现尺度上相互融合、单元上相互补充的趋势。

可以看出，上述有关国土空间开发与建设用地适宜性评价的研究，为后人提供了大 量有益借鉴。然而, 仍存在单一视角重自然、轻人文或复合视角对要素交互作用阐述薄 弱的问题; 城市、乡村地域剥离严重, 且研究重心不断向城市倾斜, 城乡融合欠缺; 沿 海地区获得更多关注, 但仅限于相对狭小的海岸带, 难以满足新时代背景下陆海统筹战 略的开发需求。国土空间开发建设适宜性具有微观与宏观层面的内涵 ${ }^{[6]}$ 。基于此, 本文将 评价内涵界定为, 微观上是否适合转化为城乡建设用地, 宏观上是否适宜承载现代化发 展尤其是工业化与城镇化的陆海国土空间。辽宁省近年来经济增长缓慢甚至出现负增长 状况，开发建设强度相应放缓，但这也为其优化国土空间开发格局、提升开发质量与效 益提供了难得的缓冲期。因此, 本文以辽宁省为例, 遵循城乡融合、陆海统筹的区域协 调发展原则, 从自然环境、经济社会、海洋功能三个维度构建适宜性评价指标体系, 开 展陆海国土空间开发建设适宜性综合评价与系统分析。

\section{1 研究方法与数据来源}

\section{1 研究区概况}

辽宁省位于我国东北地区南部，介于 $118^{\circ} 53^{\prime} \sim 125^{\circ} 46^{\prime} \mathrm{E} 、 38^{\circ} 43^{\prime} \sim 43^{\circ} 26^{\prime} \mathrm{N}$ 之间，南邻 渤海、黄海, 东与朝鲜一江之隔, 是东北地区唯一既沿海又沿边的省份。全省陆地国土 面积 14.8 万 $\mathrm{km}^{2}$, 约占全国陆地国土面积的 $1.5 \%$; 海域（大陆架）面积 15 万 $\mathrm{km}^{2}$, 海洋 功能区划面积 4.1 万 $\mathrm{km}^{2}$ 。地形大致为自北向南、自东西两侧向中部倾斜, 山地丘陵分列 东西两厢向中部平原下降，呈马蹄形向渤海倾斜，呈 “六山一水三分田” 的地貌格局。 地处北半球中纬度南半部、欧亚大陆东岸, 大陆季风气候盛行, 雨热同季, 日照丰富, 四季分明, 年均气温-5.2 11.7 ${ }^{\circ} \mathrm{C}$, 年均降水量 400 970 mm。辽宁是我国重要老工业基 地, 被誉为 “共和国长子”。截至 2016 年底, 地区生产总值 22037.8 亿元, 比 2015 年下降 $2.5 \%$; 年末常住人口 4377.8 万人, 其中, 城镇常住人口 2949.3 万人, 占 $67.37 \%$ 。由此可 见, 研究区域一方面面临如何通过国土空间政策实施提升经济社会发展动力的需求, 另 一方面也面临振兴东北战略实施所带来的未来国土空间开发建设的严峻挑战。

\section{2 数据来源}

针对不同维度国土空间开发建设适宜性评价要求及特点, 本文数据主要来源于第二 次土地调查数据、经济社会统计数据及海洋功能区划数据。

(1) 辽宁省各县（市）第二次土地调查数据。该数据来源于全国县级 1：10000第二 次土地调查成果，包括辽宁省各县（市）土地利用现状图（地块图斑数据）, 以及地类名 
称、坡度、滑坡泥石流、地面沉降、活动断层、生态用地、规划用地管制区、矿山占 用、岩溶塌陷、地质遗迹、耕地等级、基本农田等地块属性数据。经统计, 辽宁全省地 块或图斑数量为 387674 个, 平均面积约为 $0.04 \mathrm{~km}^{2}$, 评价单元满足 “均质区域” 的基本 评价要求。

(2) 辽宁省各县（市）经济社会统计数据。该数据主要针对经济社会适宜性评价维 度，其中，人均可利用水资源、人均可利用土地资源、交通优势度、人口集聚度均来自 辽宁省主体功能区划矢量图件；人均 GDP、二三产业比例和国土开发强度中的人口、 GDP、二三产业产值等数据则来自《辽宁统计年鉴》 ${ }^{[32]}$ 。

(3) 辽宁省海洋功能区划数据。该数据源自《辽宁省海洋功能区划（2011-2020 年）》 ${ }^{[33]}$, 总共 8 个类别 188 个基本单元，总面积为 $41168.87 \mathrm{~km}^{2}$, 基本单元面积差异极 大, 从 $0.39 \mathrm{~km}^{2}$ 到 $6982.70 \mathrm{~km}^{2}$ 不等。海洋功能区包括海岸和近海两类基本功能区, 前者 包含 8 个类别 167 个单元，后者则包括 6 个类别 21 个单元。两者均包含工业与城镇用海 区、港口航运区、旅游休闲娱乐区、农渔业区、海洋保护区、保留区，此外，海岸基本 功能区还包括矿产能源区与特殊利用区。海洋功能区作为海洋国土的核心组成部分, 更 为准确地表达了海洋国土空间的真实利用状况。

\section{3 研究方法}

从自然环境、经济社会、海洋功能三个维度构建辽宁省国土空间开发建设适宜性评 价指标体系（表 1)，分别测算三个维度适宜性状况，并最终获得综合适宜性评价结果。 技术流程如下:

首先，基于辽宁省各县（市）第二次土地调查数据，选择地类名称、坡度、滑坡泥 石流等 12 个影响因子 (表 1 )。根据上述因子对国土空间开发建设的适宜程度，运用特尔 斐法 ${ }^{[12-22,27]}$ 赋予不同等级或类别因子 $1 、 0.8 、 0.6 、 0.4 、 0$ 分值, 分值越高, 适宜性越强, 反之则反; 按照 “木桶原理法则” ${ }^{[3]}$ 对地块图斑因子分值叠加取小，依据分值大小划定 适宜性等级，依次为适宜、基本适宜、基本不适宜、不适宜，对应分值 1 或 $0.8 、 0.6$ 、 $0.4 、 0$, 得到自然环境适宜性。计算公式如下:

$$
f(x)=\min \left(x_{1}, x_{2}, \cdots, x_{12}\right)
$$

式中： $f(x)$ 为自然环境适宜性； $x_{1}, x_{2}, \cdots, x_{12}$ 为地块图斑因子分值。

其次, 根据科学性、全面性、简明性和可操作性指标选取原则, 选择人均可利用水 资源、国土开发强度、交通优势度、人口集聚度、人均 GDP、二三产业比重、人均可利 用土地资源 7 项经济社会因子。对上述因子划分等级，并由高到低依次赋予 $1 、 0.8$ 、 0.6、0.4、0.2 分值; 利用等权重线性加权求和法, 测算经济社会适宜性, 并利用自然断 点法划分为高适宜、较高适宜、较低适宜、低适宜 4 个等级, 分值分别对应 $0.63 \sim 0.83$ 、 0.49 0.63、0.37 0.49、0.03 0.37。计算公式如下：

$$
f(y)=\frac{1}{n} \sum_{i=1}^{n} y_{i}
$$

式中： $f(y)$ 为经济社会适宜性； $y_{i}$ 为因子不同等级分值； $n$ 为因子个数。

再次，根据国土空间开发建设适宜性的概念与内涵以及辽宁省海洋功能区划原则和 标准，本文 8 类功能区均按照一定 “适宜性” 划定，在充分评价各功能区的概念和范围 基础上, 对 8 类功能区划分适宜性等级，将工业与城镇用海区划为适宜建设区，港口航 


\section{表 1 辽宁省国土空间开发建设适宜性评价指标体系}

Table 1 The index system of suitability evaluation of spatial development and construction land in Liaoning province

\begin{tabular}{|c|c|c|c|}
\hline 准则层 & & 指标层 & 等级/分值 \\
\hline \multirow{7}{*}{$\begin{array}{l}\text { 自然环境 } \\
\text { 适宜性 }\end{array}$} & $x_{1}$ & 地类名称 & $\begin{array}{l}\text { 水田、水浇地、旱地、铁路用地、公路用地、农村道路、 } \\
\text { 机场用地、港口码头用地、管道运输用地、城市、建制 } \\
\text { 镇、村庄、采矿用地、风景名胜及特殊用地 } / 1 \text {; 其他草 } \\
\text { 地、田坎、盐碱地、裸地 } / 0.8 \text {; 果园、茶园、其他园地、灌 } \\
\text { 木林地、其他林地、坑塘水面、水工建筑用地、空闲地、物草地、沟 } \\
\text { 设施农用地 } / 0.6 \text {; 有林地、天然牧草地、人工牧草濯 } \\
\text { 渠 } / 0.4 \text {; 河流水面、湖泊水面、水库、海滩涂、内陆滩 } \\
\text { 涂、沼泽地、沙地 } / 0\end{array}$ \\
\hline & $x_{2}$ & 坡度 & $0 \sim 2^{\circ} / 1 、 2 \sim 8^{\circ} / 0.8 、 8 \sim 15^{\circ} / 0.6 、 15 \sim 25^{\circ} / 0.6 、 25^{\circ}$ 以上 $/ 0.4$ \\
\hline & $x_{3}$ & 滑坡泥石流 & 不易发区/1、低易发区/0.6、中易发区/0.6、高易发区/0.4 \\
\hline & $x_{4}$ & 地面沉降 & $\begin{array}{l}\text { 轻微或稳定区/1、一般沉降区/0.8、较严重沉降区/0.6、严 } \\
\text { 重沉降区/0.4、非沉降区/1 }\end{array}$ \\
\hline & $x_{5}$ & 活动断层 & 稳定区/1、轻微影响/0.8、较严重影响/0.8、严重影响/0.6 \\
\hline & $x_{6}$ & 生态用地 & 否/1、是/0 \\
\hline & $x_{7}$ & 规划用地管制区 & 非禁止建设区/1、禁止建设区 $/ 0$ \\
\hline \multirow{12}{*}{$\begin{array}{l}\text { 经济社会 } \\
\text { 适宜性 }\end{array}$} & $x_{8}$ & 矿山占用 & $\begin{array}{l}\text { 非占用地 } / 1 \text {; 中转用地、矿山建筑 } / 0.8 \text {; 采场 } / 0.6 \text {; 塌陷、 } \\
\text { 固体废弃 } / 0.4\end{array}$ \\
\hline & $x_{9}$ & 岩溶塌陷 & 不易发区/1、中易发区/0.8、低易发区/0.8、高易发区/0.6 \\
\hline & $x_{10}$ & 地质遗迹 & $\begin{array}{l}\text { 其他 } / 1 \text { 、缓冲区 } 4 \mathrm{~km} \times 4 \mathrm{~km} / 0.6 \text { 、缓冲区 } 6 \mathrm{~km} \times 6 \mathrm{~km} / 0.6 \text { 、缓 } \\
\text { 冲区 } 2 \mathrm{~km} \times 2 \mathrm{~km} / 0.4\end{array}$ \\
\hline & $x_{11}$ & 优质耕地 & $\begin{array}{l}\text { 非耕地 } / 1 \text { 、四等地 } / 0.4 \text { 、五等地 } / 0.4 \text { 、六等地 } / 0.6 \text { 、七等地/ } \\
0.6 \text { 、八等地 } / 0.6 \text { 、九等地 } / 0.6 \text { 、十等地以下 } / 0.8\end{array}$ \\
\hline & $x_{12}$ & 基本农田 & 否 $/ 1$ 、是 $/ 0$ \\
\hline & $y_{1}$ & 人均可利用水资源/(m³/人) & $\begin{array}{l}\geqslant 2000 / 1 、 1500 \sim 2000 / 0.8 、 1000 \sim 1500 / 0.6 、 500 \sim 1000 / 0.4 \text { 、 } \\
<500 / 0.2\end{array}$ \\
\hline & $y_{2}$ & 国土开发强度/\% & $\geqslant 40 / 1 、 15 \sim 40 / 0.8 、 11 \sim 15 / 0.6 、 7 \sim 11 / 0.4 、<7 / 0.2$ \\
\hline & $y_{3}$ & 交通优势度 & 便利 $/ 1$ 、较便利/0.8、中等/0.6、较差/0.4、差/0.2 \\
\hline & $y_{4}$ & 人口集聚度 & $\begin{array}{l}\geqslant 3.00 / 1 、 1.00 \sim 3.00 / 0.8 、 0.60 \sim 1.00 / 0.6 、 0.30 \sim 0.60 / 0.4 \text { 、 } \\
<0.30 / 0.2\end{array}$ \\
\hline & $y_{5}$ & 人均 GDP/万元 & $\begin{array}{l}\geqslant 13.63 / 1 、 7.93 \sim 13.63 / 0.8 、 5.07 \sim 7.93 / 0.6 、 3.28 \sim 5.07 / 0.4 \text { 、 } \\
1.02 \sim 3.28 / 0.2\end{array}$ \\
\hline & $y_{6}$ & 二三产业比例 $/ \%$ & $\geqslant 93 / 1 、 84 \sim 93 / 0.8 、 73 \sim 84 / 0.6 、 61 \sim 73 / 0.4 、 46 \sim 61 / 0.2$ \\
\hline & $y_{7}$ & 人均可利用土地资源 $/\left(\mathrm{hm}^{2} /\right.$ 人 $)$ & $\begin{array}{l}\geqslant 0.20 / 1 、 0.15 \sim 0.20 / 0.8 、 0.10 \sim 0.15 / 0.6 、 0.05 \sim 0.10 / 0.4 \\
<0.05 / 0.2\end{array}$ \\
\hline $\begin{array}{l}\text { 海洋功能 } \\
\text { 适宜性 }\end{array}$ & $z$ & 海洋功能区 & $\begin{array}{l}\text { 工业与城镇用海区/适宜; 港口航运区、矿产能源区、旅游 } \\
\text { 休闲娱乐区/基本适宜; 特殊利用区/基本不适宜; 农渔业 } \\
\text { 区、海洋保护区、保留区/不适宜 }\end{array}$ \\
\hline
\end{tabular}

运区、矿产能源区、旅游休闲娱乐区划为基本适宜建设区，特殊利用区划为基本不适宜 建设区，农渔业区、海洋保护区、保留区划为不适宜建设区。计算公式如下:

$$
f(z)=f\left(z_{1}, z_{2}, z_{3}, z_{4}\right)
$$

式中： $f(z)$ 为海洋功能适宜性； $z_{1} 、 z_{2} 、 z_{3} 、 z_{4}$ 分别为合并重组后适宜、基本适宜、基 本不适宜、不适宜4类海洋功能适宜性类型。

最后，为表征自然环境与经济社会的交互作用，对两者进行乘积运算，通过对运算 结果数据特征及现实情况的反复分析，重新划定适宜性等级，依次为适宜、基本适宜、 
基本不适宜、不适宜，阈值区间分别为 $0.49<f(x) \times f(y) 、 0.37<f(x) \times f(y) \leqslant 0.49 、 0<$ $f(x) \times f(y) \leqslant 0.37 、 0$; 并与海洋功能适宜性叠加, 重叠部分以海洋功能适宜性评价结果为 准，获得综合适宜性评价结果。

$$
f(x, y, z)=f(x) \times f(y)+f(z)
$$

式中: $f(x, y, z)$ 为综合适宜性; $f(x) 、 f(y) 、 f(z)$ 分别为自然环境适宜性、经济社会 适宜性、海洋功能适宜性。

\section{2 结果分析}

\section{1 自然环境适宜性}

自然环境适宜性反映地区自然环境本底及现状特征对国土空间开发建设的适宜程 度，对区域国土空间开发建设活动具有基础性、决定性作用。如图 1 所示，自然环境适 宜性空间分异明显，不同等级、不同地域适宜性集聚分散特征差异明显。如表 2 所示, 适宜性面积由高到低为基本不适宜、不适宜、基本适宜、适宜，依次为 $49503.08 \mathrm{~km}^{2}$ 、 $46369.74 \mathrm{~km}^{2} 、 36727.47 \mathrm{~km}^{2} 、 15823.85 \mathrm{~km}^{2}$ ，分别占陆地国土的 $33.35 \% 、 31.24 \%$ 、 $24.74 \% 、 10.66 \%$ 。可知，“不适宜”（不适宜与基本不适宜）建设区比例高达 $64.59 \%$ ，近 两倍于 “适宜”（适宜与基本适宜）建设区。

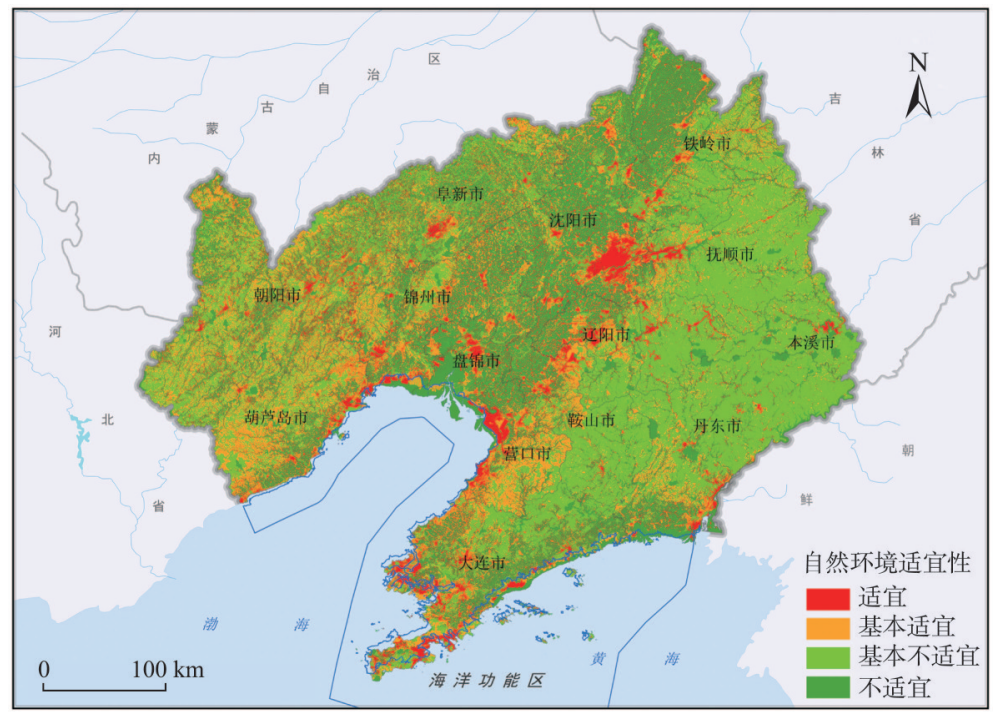

图 1 辽宁省自然环境适宜性

Fig. 1 The suitability of natural environment in Liaoning province

适宜建设区集中分布于辽宁省中部的辽河平原与南部滨海平原，以现状城镇用地与 农村居民点为主，两者在空间形态和分布格局上差异明显，前者分布于辽河平原铁岭 一沈阳一辽阳一营口一线，以及滨海平原葫芦岛一锦州一盘锦一营口一丹东一线，呈高 密度、大斑块形态与集聚特征，后者则以小斑块、破碎化形态遍布全境; 大连、沈阳、 朝阳面积位列前三，均超过 $2000 \mathrm{~km}^{2}$ ，本溪面积最小，仅为 $153.07 \mathrm{~km}^{2}$ 。基本适宜建设 区主要分布于城镇及农村周边、辽河平原向辽东山地的狭长过渡地带，以及辽西低山丘 
表 2 辽宁省自然环境适宜性评价结果

Table 2 The results of natural environment suitability in Liaoning province

\begin{tabular}{|c|c|c|c|c|c|c|c|c|}
\hline \multirow{2}{*}{ 名称 } & \multicolumn{2}{|c|}{ 适宜 } & \multicolumn{2}{|c|}{ 基本适宜 } & \multicolumn{2}{|c|}{ 基本不适宜 } & \multicolumn{2}{|c|}{ 不适宜 } \\
\hline & 面积 $/ \mathrm{km}^{2}$ & 占比 $/ \%$ & 面积 $/ \mathrm{km}^{2}$ & 占比 $/ \%$ & 面积 $/ \mathrm{km}^{2}$ & 占比 $/ \%$ & 面积 $/ \mathrm{km}^{2}$ & 占比 $/ \%$ \\
\hline 辽宁省 & 15823.85 & 10.66 & 36727.47 & 24.74 & 49503.08 & 33.35 & 46369.74 & 31.24 \\
\hline 沈阳市 & 2237.56 & 17.40 & 2200.45 & 17.12 & 1514.43 & 11.78 & 6904.27 & 53.70 \\
\hline 大连市 & 2438.82 & 17.89 & 3254.49 & 23.88 & 3712.03 & 27.23 & 4225.90 & 31.00 \\
\hline 鞍山市 & 808.91 & 8.72 & 1964.55 & 21.18 & 4075.51 & 43.95 & 2424.91 & 26.15 \\
\hline 抚顺市 & 517.79 & 4.59 & 2331.53 & 20.69 & 7015.20 & 62.24 & 1406.50 & 12.48 \\
\hline 本溪市 & 153.07 & 1.82 & 1256.79 & 14.94 & 5736.31 & 68.18 & 1267.76 & 15.07 \\
\hline 丹东市 & 806.56 & 5.28 & 2323.59 & 15.20 & 8678.94 & 56.76 & 3480.52 & 22.76 \\
\hline 锦州市 & 1408.33 & 14.02 & 2961.50 & 29.48 & 1477.42 & 14.70 & 4200.15 & 41.80 \\
\hline 营口市 & 856.86 & 15.82 & 2367.08 & 43.71 & 925.37 & 17.09 & 1266.37 & 23.38 \\
\hline 阜新市 & 1238.44 & 11.99 & 2397.33 & 23.21 & 2601.94 & 25.20 & 4089.28 & 39.60 \\
\hline 辽阳市 & 553.33 & 11.68 & 1091.56 & 23.05 & 1502.70 & 31.73 & 1588.19 & 33.54 \\
\hline 盘锦市 & 586.43 & 14.42 & 624.86 & 15.37 & 261.50 & 6.43 & 2592.61 & 63.77 \\
\hline 铁岭市 & 1040.30 & 8.01 & 2570.95 & 19.80 & 3682.73 & 28.36 & 5690.53 & 43.83 \\
\hline 朝阳市 & 2161.08 & 10.97 & 6892.18 & 34.99 & 5705.72 & 28.97 & 4938.80 & 25.07 \\
\hline 葫芦岛市 & 1016.38 & 9.76 & 4490.61 & 43.12 & 2613.26 & 25.09 & 2293.96 & 22.03 \\
\hline
\end{tabular}

陵的广阔地区; 其中，辽西的朝阳、葫芦岛面积高达 $6892.18 \mathrm{~km}^{2} 、 4490.61 \mathrm{~km}^{2}$ 。基本不 适宜建设区以辽河平原为界东西两侧分布，东侧以大面积连片状林地为主，西侧则以斑 块状、破碎化林草混合地为主。不适宜建设区以耕地、水域湿地为代表，分布于中部的 辽河平原、南部的滨海平原, 以及辽西低山丘陵; 此外, 辽东山地中部亦有相当数量的 大面积斑块分布。特别需要注意的是, 适宜与不适宜建设区于辽河平原、滨海平原交错 分布, 开发与保护矛盾尤为突出。

\section{2 经济社会适宜性}

经济社会适宜性表征地区经济社会发展水平及国土空间开发潜力，直接反映地区对 开发建设活动的总体需求和支撑能力，体现国土空间开发建设对质量和效益的要求。

如图 2 所示，经济社会适宜性总体呈现明显的中心外围分布特征，以沈阳经济区为 核心向周边递减，以辽宁沿海经济带为轴带向内陆递减。具体来看，高适宜建设区集中 分布于沈阳经济区的沈阳、抚顺、鞍山、本溪、辽阳等城市中心市辖区，以及辽宁沿海 经济带的葫芦岛、盘锦、营口、大连等城市中心市辖区，特别是辽东湾东侧的盘锦一大 连一线, 前者以组团状集聚分布于辽宁中部, 后者则以条带状离散分布于辽宁南部沿 海, 这里是全省经济社会发展程度最高的地区, 开发建设活动强烈, 同时也是人地关系 矛盾突出的地区，人口资源环境压力巨大。较高适宜建设区分布于高适宜建设区外围， 以上述城市中心市辖区周边和其他经济社会发展程度较高的县市为主，这些地区经济社 会发展程度仅次于高适宜建设区, 且开发强度和完备程度均低于高适宜建设区，由于城 市中心市辖区开发较早且相对完善, 使得较高适宜建设区更可能成为未来开发建设的潜 在区域。较低适宜建设区分布于辽东的抚顺、本溪、丹东等地, 以及辽西的阜新、葫芦 岛、锦州交界地带，同时，沈阳北部亦有大面积分布。低适宜建设区分布于辽西的葫芦 


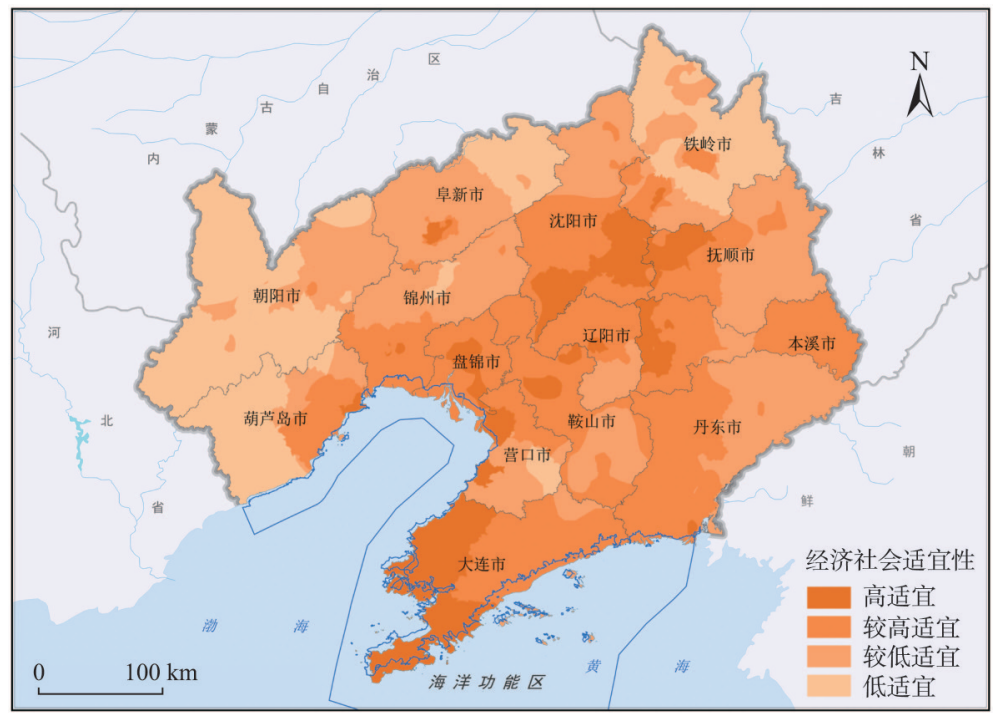

图 2 辽宁省经济社会适宜性

Fig. 2 The suitability of economy and society in Liaoning province

岛、朝阳、阜新，此外，铁岭、辽阳、鞍山也有一定面积分布。

\section{3 海洋功能适宜性}

海洋功能适宜性根据地区沿海自然环境特点、自然资源优势、海域开发利用现状、 环境保护及社会发展需求划定适宜性等级区域，体现海洋国土空间对开发建设活动的适 宜程度。辽宁省海洋功能区呈 “天鹅” 形态横跨渤海、黄海, 面积为 $41168.87 \mathrm{~km}^{2}$; 其 中, 工业与城镇用海区 $1052.65 \mathrm{~km}^{2}$ 、港口航运区 $3036.41 \mathrm{~km}^{2}$ 、矿产能源区 $204.47 \mathrm{~km}^{2}$ 、 旅游休闲娱乐区 $837.11 \mathrm{~km}^{2}$ 、特殊利用区 $391.70 \mathrm{~km}^{2}$ 、农渔业 $19601.43 \mathrm{~km}^{2}$ 、海洋保护区 $4663.10 \mathrm{~km}^{2}$ 、保留区 $11382.02 \mathrm{~km}^{2}$ 。经统计，适宜、基本适宜、基本不适宜、不适宜建 设区面积依次为 $1052.65 \mathrm{~km}^{2} 、 4077.99 \mathrm{~km}^{2} 、 391.70 \mathrm{~km}^{2} 、 35646.54 \mathrm{~km}^{2}$, 分别占海洋功能 区的 $2.56 \% 、 9.91 \% 、 0.95 \% 、 86.59 \%$ 。

如图 3 所示，适宜建设区即工业与城镇用海区，主要分布于辽西海域的葫芦岛、锦 州和辽东半岛西部海域的大连、营口、盘锦, 以及辽东半岛东部海域的大连、丹东近海 地区; 其中, 大连面积最高为 $484.32 \mathrm{~km}^{2}$, 丹东最小为 $54.98 \mathrm{~km}^{2}$ 。基本适宜建设区包括 港口航运区、矿产能源区、旅游休闲娱乐区，海域分布范围广阔；其中，大连面积最多 为 $1817.44 \mathrm{~km}^{2}$ ，盘锦最少为 $163.73 \mathrm{~km}^{2}$ 。基本不适宜建设区即特殊利用区，分布于辽东 半岛南部海域的大连及辽西海域的葫芦岛, 面积分别为 $347.23 \mathrm{~km}^{2} 、 44.47 \mathrm{~km}^{2}$, 其他地 区没有分布。不适宜建设区包括农渔业区、海洋保护区、保留区，分布于陆地向海洋延 伸的广阔空间，自最西端的辽西海域到最东端的辽东半岛东部海域均有分布；其中，大 连面积最多为 $20006.26 \mathrm{~km}^{2}$ 。可知, “适宜” 建设区面积为 $5130.64 \mathrm{~km}^{2}$, 占海洋功能区的 $12.47 \%$ ，占比远低于自然环境 “适宜”建设区的 $35.40 \%$ ，可供直接开发建设空间有限。 此外, 海洋功能适宜性空间分布极不均衡，不仅体现在海洋功能区划上，还体现在不同 适宜性分布上。作为东北地区最大的港口城市，大连拥有最为广阔的海洋空间，不同等 级适宜性面积均位居首位，但 “不适宜”建设区比例高达 $93.38 \%$ ，远高于 “适宜”建设 


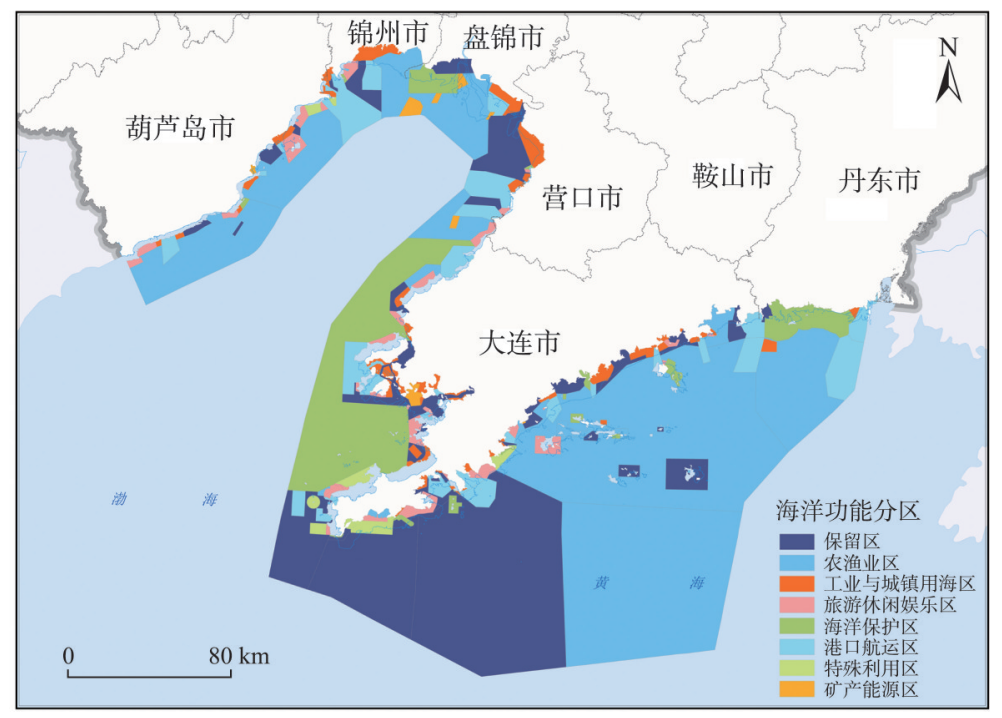

图 3 辽宁省海洋功能区划

Fig. 3 The marine functional zoning of Liaoning province

区的 $6.62 \%$ 。

\section{4 综合适宜性评价}

综合适宜性系统集成了自然环境、经济社会、海洋功能三个维度的评价结果，体现 了陆海统筹视角下沿海地区更为 “真实” 的国土开发建设空间，是对适宜性评价全方 位、多维度、深层次的理解与认知。如图 4 所示，辽宁省综合适宜性空间分异更为明 显，“适宜”建设区收缩明显，以沈大线、滨海线为轴带集聚分布，适宜与基本适宜建设 区呈中心外围分布格局；“不适宜”建设区扩张显著，尤以辽西低山丘陵区为典型代表。 “不适宜” 以“适宜”建设区为轴带对称分布，即不适宜建设区以滨海线为轴带南北对称 分布，基本不适宜建设区以沈大线为轴带东西对称分布，区域国土空间开发建设与保护 格局更为完整、清晰。如表 3 所示，综合适宜性由高到低为不适宜、基本不适宜、基本 适宜、适宜, 面积依次为 $68720.99 \mathrm{~km}^{2} 、 66833.96 \mathrm{~km}^{2} 、 22645.34 \mathrm{~km}^{2} 、 15504.39 \mathrm{~km}^{2}$, 分 别占陆海国土的 $39.56 \% 、 38.48 \% 、 13.04 \% 、 8.93 \%$ 。

经济社会适宜性、海洋功能适宜性从不同层面修正并重构了自然环境适宜性的空间 格局与数量特征，更为全面地展现了辽宁省国土空间开发建设的适宜状况。经济社会对 自然环境的修正作用或两者的交互作用，主要体现在基本适宜建设区向沈大轴线、滨海 轴线收缩明显, 面积为 $19172.45 \mathrm{~km}^{2}$, 较之自然环境适宜性, 面积减少了 $17555.02 \mathrm{~km}^{2}$, 比例减少了 $11.7 \%$; 其中，朝阳、葫芦岛、铁岭减少显著。基本不适宜建设区向沈大轴 线、滨海轴线明显扩张, 面积为 $66664.20 \mathrm{~km}^{2}$, 较之自然环境适宜性, 面积增加了 $17161.12 \mathrm{~km}^{2}$, 比例增加了 $11.74 \%$; 其中, 朝阳、葫芦岛、铁岭增加明显。适宜与不适 宜建设区修正前后总面积变化不大，但不同地市有所差异，适宜建设区中大连、鞍山、 沈阳面积增加较多, 朝阳、阜新、铁岭减少明显, 而不适宜建设区中地市面积变化不 大。海洋功能区的引人进一步重构了辽宁省国土空间, 陆海统筹视角下的国土面积较之 陆地国土增加了 $25280.54 \mathrm{~km}^{2}$, 国土空间类型与范围得到了极大的提升。但由于海洋国 土本身属性，其可供直接开发建设空间有限，而保护空间广阔，国土空间开发建设与生 


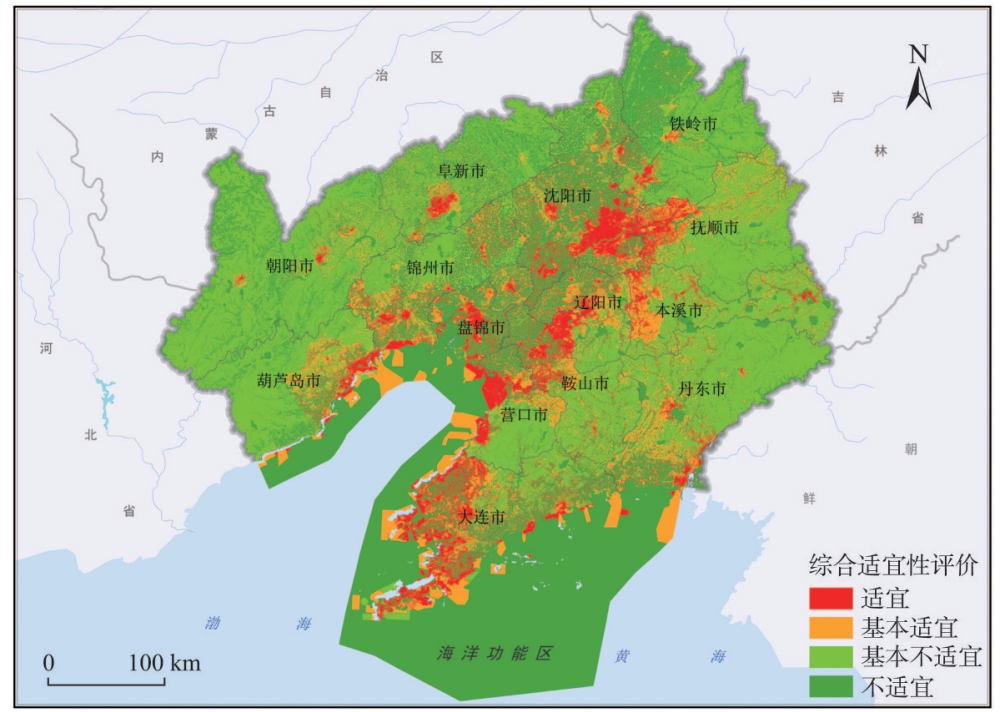

图4 辽宁省综合适宜性

Fig. 4 The comprehensive suitability of spatial development and construction land in Liaoning province

表 3 辽宁省综合适宜性评价结果

Table 3 The results of comprehensive suitability evaluation in Liaoning province

\begin{tabular}{|c|c|c|c|c|c|c|c|c|}
\hline \multirow{2}{*}{ 名称 } & \multicolumn{2}{|c|}{ 适宜 } & \multicolumn{2}{|c|}{ 基本适宜 } & \multicolumn{2}{|c|}{ 基本不适宜 } & \multicolumn{2}{|c|}{ 不适宜 } \\
\hline & 面积 $/ \mathrm{km}^{2}$ & 占比 $/ \%$ & 面积 $/ \mathrm{km}^{2}$ & 占比 $/ \%$ & 面积 $/ \mathrm{km}^{2}$ & 占比 $/ \%$ & 面积 $/ \mathrm{km}^{2}$ & 占比 $/ \%$ \\
\hline 辽宁省 & 15504.39 & 8.93 & 22645.34 & 13.04 & 66833.96 & 38.48 & 68720.99 & 39.56 \\
\hline 沈阳市 & 2850.74 & 22.17 & 1579.48 & 12.28 & 1525.41 & 11.86 & 6904.27 & 53.69 \\
\hline 大连市 & 3825.32 & 11.27 & 3900.41 & 11.49 & 2564.63 & 7.56 & 23651.69 & 69.68 \\
\hline 鞍山市 & 1633.71 & 17.65 & 1482.87 & 16.02 & 3717.66 & 40.17 & 2421.13 & 26.16 \\
\hline 抚顺市 & 1036.99 & 9.20 & 1882.86 & 16.71 & 6939.46 & 61.57 & 1411.72 & 12.53 \\
\hline 本溪市 & 179.89 & 2.29 & 1713.58 & 21.80 & 4845.87 & 61.65 & 1121.05 & 14.26 \\
\hline 丹东市 & 789.25 & 4.82 & 2732.75 & 16.69 & 8991.06 & 54.91 & 3860.89 & 23.58 \\
\hline 锦州市 & 1038.43 & 9.46 & 2153.99 & 19.62 & 2991.69 & 27.24 & 4797.19 & 43.69 \\
\hline 营口市 & 1041.50 & 16.71 & 1363.72 & 21.88 & 2379.14 & 38.17 & 1448.01 & 23.23 \\
\hline 阜新市 & 356.98 & 3.46 & 943.57 & 9.14 & 4937.16 & 47.81 & 4089.28 & 39.60 \\
\hline 辽阳市 & 646.66 & 13.65 & 1117.42 & 23.60 & 1383.51 & 29.21 & 1588.19 & 33.54 \\
\hline 盘锦市 & 857.03 & 17.95 & 595.64 & 12.47 & 127.23 & 2.66 & 3195.01 & 66.91 \\
\hline 铁岭市 & 471.21 & 3.61 & 701.54 & 5.38 & 6182.53 & 47.39 & 5690.53 & 43.62 \\
\hline 朝阳市 & 122.27 & 0.62 & 794.58 & 4.03 & 13802.06 & 70.07 & 4978.87 & 25.28 \\
\hline 葫芦岛市 & 654.40 & 5.30 & 1682.92 & 13.63 & 6446.55 & 52.21 & 3563.16 & 28.86 \\
\hline
\end{tabular}

态环境保护之间的矛盾依然严峻。此外, 较之陆地适宜性, 海洋功能适宜性差异更大, 空间分布也极不均衡。

\section{3 结论与讨论}

本文遵循城乡融合、陆海统筹原则，从自然环境、经济社会、海洋功能三个维度构 
建了适宜性评价指标体系, 系统集成了特尔斐法、木桶原理法则、线性加权求和法及多 要素空间叠置分析等方法，评价并分析了辽宁省国土空间开发建设适宜性。结论如下：

（1）综合适宜性空间分异明显，“适宜”建设区以沈大线、滨海线为轴带集聚分布, 适宜与基本适宜建设区呈明显的中心外围分布格局，“不适宜”建设区以“适宜”建设区 为轴带对称分布，即不适宜建设区以滨海线为轴带南北对称分布，基本不适宜建设区以 沈大线为轴带东西对称分布; 适宜、基本适宜、基本不适宜、不适宜建设区面积依次为 $15504.39 \mathrm{~km}^{2} 、 22645.34 \mathrm{~km}^{2} 、 66833.96 \mathrm{~km}^{2} 、 68720.99 \mathrm{~km}^{2}$, 分别占陆海国土的 $8.93 \%$ 、 $13.04 \% 、 38.48 \% 、 39.56 \%$ 。

（2）自然环境适宜性对区域国土空间开发建设具有基础性、决定性作用，不同等 级、不同区域自然环境适宜性集聚与分散特性差异显著，主要表现在东一中一西、沿海 一内陆、城镇一乡村三个层面; 适宜、基本适宜、基本不适宜、不适宜建设区面积依次 为 $15823.85 \mathrm{~km}^{2} 、 36727.47 \mathrm{~km}^{2} 、 49503.08 \mathrm{~km}^{2} 、 46369.74 \mathrm{~km}^{2}$, 分别占陆地国土的 $10.66 \% 、 24.74 \% 、 33.35 \% 、 31.24 \%$ ，“不适宜”建设区近两倍于 “适宜”建设区。

（3）经济社会适宜性总体呈现明显的中心外围分布特征，以沈阳经济区为核心向周 边递减, 以辽宁沿海经济带为轴带向内陆递减; 其对自然环境适宜性的修正作用体现在 基本适宜建设区明显收缩、基本不适宜建设区显著扩张、适宜建设区则由于地区差异而 不同程度地增加或减少。

（4）海洋功能适宜性空间分布极不均衡，适宜、基本适宜、基本不适宜、不适宜建 设区面积依次为 $1052.65 \mathrm{~km}^{2} 、 4077.99 \mathrm{~km}^{2} 、 391.70 \mathrm{~km}^{2} 、 35646.54 \mathrm{~km}^{2}$, 分别占海洋功能 区的 $2.56 \% 、 9.91 \% 、 0.95 \% 、 86.59 \%$; 海洋功能区的引入拓展了辽宁省国土空间范围， 但其可供直接开发建设空间有限，而保护空间广阔，国土空间开发建设与生态环境保护 之间的矛盾依然严峻。

本文的适宜性评价是基于陆海统筹视角的一次尝试，针对不同维度特性选择合理的 评价方法，以试图还原沿海地区更为 “真实”的国土空间开发建设适宜状况。然而，仍 有若干问题尚需讨论或解决。多要素空间叠置在适宜性评价中应用最为广泛, 因子选 取、分值权重设定以及适宜性等级划分尤为重要，特尔斐法、线性加权求和等方法难免 存在一定的主观成分，但仍对中宏观尺度适宜性评价具有借鉴意义。此外，经济社会对 自然环境的修正，由于地区经济社会发展差异，加之上述主观成分的存在，可能会对局 地适宜性结果造成一定程度的夸大或缩小。海洋国土空间的引人，一定程度上弥补了传 统适宜性评价中对 “国土空间” 的单一认知，文中将海洋功能区划成果直接应用于适宜 性评价。由于海洋功能区划自身特点或局限, 如海洋功能区块面积过大、与陆地存在重 叠或间隙等, 致使海洋功能适宜性评价存在一定的不确定性。但作为海洋详细数据暂缺 情况下的尝试，“海洋功能区划成果” 不失为一种相对恰当的选择。通过构建海洋国土空 间开发建设适宜性评价指标体系，并划定均质评价单元，无疑将更为科学、更为准确地 达到对海洋国土空间开发建设活动适宜状况的评价和认知。与此同时，陆地与海洋国土 空间在开发内涵、开发方式上存在较大差异，文中通过适宜性 “加和” 的方式表征陆海 统筹思想和原则, 思路方法直观简洁。但应注意到, 由于陆地和海洋国土空间开发建设 差异巨大，未来应更侧重陆海统筹视角下新方法、新手段的研发，以满足陆海国土空间 开发建设适宜性评价过程中对其在经济意义、地理意义及统计意义上详细化、差异化的 
解释与分析, 进而更加关注陆地与海洋在自然、经济、生态等层面的联动与交互作用机制。

致谢: 感谢辽宁省国土资源厅以及江苏苏地源土地整理规划设计有限公司在论文研究中 给予的帮助与支持。

\section{参考文献(References):}

[1] 习近平. 决胜全面建成小康社会夺取新时代中国特色社会主义伟大胜利. 人民日报, 2017-10-28(001). [XI J P. Secure a decisive victory in building a moderately prosperous society in all respects and strive for the great success of socialism with Chinese characteristics for a New Era. People's Daily, 2017-10-28(001).]

[2] 中华人民共和国国务院. 全国国土规划纲要 (2016-2030年). http://www.gov.cn/zhengce/content/201702/04/content 5165309.htm, 2017-01-03. [State Council of the People's Republic of China. Outline of the national overall planning on land use (2006-2020). http://www.gov.cn//Zhengce/content/201702/04/content_5165309.htm, 2017-01-03.]

[3] 黄贤金. 论土地生态经济学与国土空间用途管制: 兼论王万茂教授《土地生态经济学》的学科贡献. 中国土地科学, 2018, 32(2): 1-5. [HUANG X J. On land eco-economics and territorial space use control: The academic contribution of the work "Land Eco-Economics". China Land Sciences, 2018, 32(2): 1-5.]

[4] 史同广, 郑国强, 王智勇, 等. 中国土地适宜性评价研究进展. 地理科学进展, 2007, 26(2): 106-115. [SHI T G, ZHENG G Q, WANG Z Y, et al. Progress in research on land suitability evaluation in China. Progress in Geography, 2007, 26(2): 106-115.]

[5] 李坤, 岳建伟. 我国建设用地适宜性评价研究综述. 北京师范大学学报: 自然科学版, 2015, 51(S1): 107-113. [LI K, YUE J W. Evaluation of construction land suitability in China: A review. Journal of Beijing Normal University: Nature Science, 2015, 51(S1): 107-113.]

[6] 喻忠否, 张文新, 梁进社, 等. 国土空间开发建设适宜性评价研究进展. 地理科学进展, 2015, 34(9): 1107-1122. [YU Z L, ZHANG W X, LIANG J S, et al. Progress in evaluating suitability of spatial development and construction land. Progress in Geography, 2015, 34(9): 1107-1122.]

[7] MCHARG I L, MUMFORD L. Design with Nature. New York: American Museum of Natural History, 1969.

[8] 王海鹰, 张新长, 康停军. 基于 GIS 的城市建设用地适宜性评价理论与应用. 地理与地理信息科学, 2009, 25(1): 1417. [WANG H Y, ZHANG X C, KANG T J. Theory and application of evaluation on ecological applicability for urban construction land based on GIS. Geography and Geo-information Science, 2009, 25(1): 14-17.]

[9] MALCZEWSKI J. GIS-based land-use suitability analysis: A critical overview. Progress in Planning, 2004, 62(1): 3-65.

[10] 邱炳文, 池天河, 王钦敏, 等. GIS 在土地适宜性评价中的应用与展望. 地理与地理信息科学, 2004, 20(5): 20-23, 44. [QIU B W, CHI T H, WANG Q M, et al. Application of GIS and its prospect in land suitability assessment. Geography and Geo-information Science, 2004, 20(5): 20-23, 44.]

[11] PEREIRA J M C, DUCKSTEIN L. A multiple criteria decision-making approach to GIS-based land suitability evaluation. International Journal of Geographical Information Science, 1993, 7(5): 407-424.

[12] STEINER F, MCSHERRY L, COHEN J. Land suitability analysis for the upper Gila River Watershed. Landscape and Urban Planning, 2000, 50(4): 199-214.

[13] 宗跃光, 王蓉, 汪成刚, 等. 城市建设用地生态适宜性评价的潜力一限制性分析: 以大连城市化区为例. 地理研究, 2007, 36(6): 1117-1126, 1305. [ZONG Y G, WANG R, WANG C G, et al. Ecological suitability assessment on land use based on potential-constrain approach: The case of urbanized areas in Dalian city, China. Geographical Research, 2007, 36(6): 1117-1126, 1305.]

[14] 唐常春, 孙威. 长江流域国土空间开发适宜性综合评价. 地理学报, 2012, 67(12): 1587-1598. [TANG C C, SUN W. Comprehensive evaluation of land spatial development suitability of the Yangtze River Basin. Acta Geographica Sinica, 2012, 67(12): 1587-1598.]

[15] 焦胜, 李振民, 高青, 等. 景观连通性理论在城市土地适宜性评价与优化方法中的应用. 地理研究, 2013, 32(4): 720730. [JIAO S, LI Z M, GAO Q, et al. The application of landscape connectivity theory in urban ecology suitability assessment and optimization. Geographical Research, 2013, 32(4): 720-730.]

[16] 秦天天, 齐伟, 李云强, 等. 基于生态位的山地农村居民点适宜度评价. 生态学报, 2012, 32(16): 5175-5183. [QIN T T, QI W, LI Y Q, et al. Suitability evaluation of rural residential land based on niche theory in mountainous area. Acta Ecologica Sinica, 2012, 32(16): 5175-5183.] 
[17] HALL G B, WANG F, SUBARYONO. Comparison of Boolean and fuzzy classification methods in land suitability analysis by using geographical information systems. Environment and Planning A, 1992, 24(4): 497-516.

[18] XU K, KONG C, LI J, et al. Suitability evaluation of urban construction land based on geo-environmental factors of Hangzhou, China. Computers \& Geosciences, 2011, 37(8): 992-1002.

[19] 陈诚, 陈雯, 吕卫国. 基于空间开发适宜性分区的城镇建设用地配置: 以海安县为例. 地理科学进展, 2009, 28(5): 775-781. [CHEN C, CHEN W, LYU W G. Allocation of urban construction land based on the regionalization of spatial development suitability: A case study of Haian county. Progress in Geography, 2009, 28(5): 775-781.]

[20] 刘孝富, 舒俭民, 张林波. 最小累积阻力模型在城市土地生态适宜性评价中的应用: 以厦门为例. 生态学报, 2010, 30(2): 421-428. [LIU X F, SHU J M, ZHANG L B. Research on applying minimal cumulative resistance model in urban land ecological suitability assessment: As an example of Xiamen city. Acta Ecologica Sinica, 2010, 30(2): 421-428.]

[21] 何丹, 金凤君, 周璟. 资源型城市建设用地适宜性评价研究: 以济宁市大运河生态经济区为例. 地理研究, 2011, 30 (4): 655-666. [HE D, JIN F J, ZHOU J. Urban construction land suitability evaluation in resource-based cities: Taking the Grand Canal Ecologic and Economic Area as an example. Geographical Research, 2011, 30(4): 655-666.]

[22] 尹海伟, 张琳琳, 孔繁花, 等. 基于层次分析和移动窗口方法的济南市建设用地适宜性评价. 资源科学, 2013, 35(3): 530-535. [YIN H W, ZHAGN L L, KONG F H, et al. Suitability evaluation of urban construction land in Jinan city based on AHP and moving window methods. Resources Science, 2013, 35(3): 530-535.]

[23] 吴艳娟, 杨艳昭, 杨玲, 等. 基于 “三生空间”的城市国土空间开发建设适宜性评价: 以宁波市为例. 资源科学, 2016, 38(11): 2072-2081. [WU Y J, YANG Y Z, YANG L, et al. Land spatial development and suitability for city construction based on ecological-living-industrial space: Take Ningbo city as an example. Resources Science, 2016, 38(11): 20722081.]

[24] 罗婧, 姚亦锋, 盛鸣, 等. 基于 GIS 的陇南灾区建设用地适宜性评价. 长江流域资源与环境, 2009, 18(6): 540-544. [LUO J, YAO Y F, SHENG M, et al. Evaluation of potential land use in the region of Longnan based on GIS. Resources and Environment in the Yangtze Basin, 2009, 18(6): 540-544.]

[25] 王成金, 张岸. 基于交通优势度的建设用地适宜性评价与实证: 以玉树地震灾区为例. 资源科学, 2012, 34(9): 16881697. [WANG C J, ZHANG A. Evaluation of transport dominance and delimitation of land suitability for construction in the Yushu Earthquake region. Resources Science, 2012, 34(9): 1688-1697.]

[26] 魏海, 秦博, 彭建, 等. 基于 GRNN模型与邻域计算的低丘缓坡综合开发适宜性评价: 以乌蒙山集中连片特殊困难 片区为例. 地理研究, 2014, 33(5): 831-841. [WEI H, QIN B, PENG J, et al. Evaluation on comprehensive exploitation suitability of low-slope hilly land based on GRNN model and neighborhood calculation: A case study of Wumeng Mountain continuous poverty-stricken region. Geographical Research, 2014, 33(5): 831-841.]

[27] 齐增湘, 廖建军, 徐卫华, 等. 基于 GIS 的秦岭山区聚落用地适宜性评价. 生态学报, 2015, 35(4): 1274-1283. [QI Z X, LIAO J J, XU W H, et al. Suitability analysis of mountain settlements in Qinling using a GIS system. Acta Ecologica Sinica, 2015, 35(4): 1274-1283.]

[28] 杨子生. 山区城镇建设用地适宜性评价方法及应用: 以云南省德宏州为例. 自然资源学报, 2016, 31(1): 64-76. [YANG Z S. Land suitability evaluation for urban construction and its application in mountainous areas: A case study in Dehong Dai-Jingpo Autonomous Prefecture, Yunnan province. Journal of Natural Resources, 2016, 31(1): 64-76.]

[29] 党丽娟, 徐勇, 汤青, 等. 广西西江沿岸后备适宜建设用地潜力及空间分布. 自然资源学报, 2014, 29(3): $387-397$. [DANG L J, XU Y, TANG Q, et al. Potential and spatial distribution of suitable construction land along the Xijiang Riverside in Guangxi. Journal of Natural Resources, 2014, 29(3): 387-397.]

[30] 李伟芳, 俞腾, 李加林, 等. 海岸带土地利用适宜性评价: 以杭州湾南岸为例. 地理研究, 2015, 34(4): 701-710. [LI W F, YU T, LI J L, et al. Suitability evaluation of land use in coastal zones: A case study in Southern Hangzhou Bay. Geographical Research, 2015, 34(4): 701-710.]

[31] 高永年, 鲍桂叶, 王静, 等. 江苏沿海地区可承载城乡建设用地能力及匹配性评价. 自然资源学报, 2015, 30(8): 1278-1288. [GAO Y N, BAO G Y, WANG J, et al. Carrying capability and matching evaluation of urban and rural construction land in the coastal areas of Jiangsu province. Journal of Natural Resources, 2015, 30(8): 1278-1288.]

[32] 辽宁省统计局. 辽宁省统计年鉴. 北京: 中国统计出版社, 2015. [Liaoning Provinical Bureau of Statistics. Liaoning Statistical Yearbook. Beijing: China Statistics Press, 2015.]

[33] 辽宁省人民政府. 辽宁省海洋功能区划 (2011-2020 年). http://lnhyw.gov.cn/xzwgk/flfg.flqt.201712/t20171205_ 3124937.html. [The People's Government of Liaoning Province. Marine Functional Zoning of Liaoning Province (20112020). http://nhyw.gov.cn/xzwgk/flfg.flqt.201712/t20171205_3124937.html.] 


\title{
Comprehensive suitability evaluation of spatial development and construction land in the perspective of land-ocean co-ordination:
}

\author{
A case study of Liaoning province, China
}

\author{
JI Xue-peng, HUANG Xian-jin, CHEN Yi, WANG Dan-yang, SONG Ya-ya \\ (School of Geographic and Oceanographic Sciences, Nanjing University, Nanjing 210023, China)
}

\begin{abstract}
Comprehensive suitability evaluation of spatial development and construction land is the scientific basis and guarantee for optimizing spatial development pattern and improve its quality and efficiency. It is of great significance for the implementation of regional coordinated development strategy. In this paper, according to the principles of urban-rural integration and land-ocean co-ordination, we selected Liaoning province as a case, the only both coastal and border province in Northeast China. The suitability evaluation index system was established from 3 dimensions, including natural environment, economy and society, and marine function. To evaluate and analyze the suitability of spatial development and constructive land in this province, we integrated the application of Delphi method, cask theory, linear weighted summation model and multi-factors space overlay analysis. The results show that there exist obvious characteristics of spatial differentiation in the suitability of spatial development and construction land throughout Liaoning. The most and more suitable construction land represent an obvious central peripheral structure, and concentrate along both the Shenyang-Dalian axis and the Binhai axis; the most unsuitable construction land shows a north-south symmetric distribution by the Binhai axis, while the more unsuitable construction land shows an east-west symmetric distribution by the Shenyang- Dalian axis. The construction land areas of most suitability, more suitability, more unsuitability, and most unsuitability are $15504.39 \mathrm{~km}^{2}$, $22645.34 \mathrm{~km}^{2}, 66833.96 \mathrm{~km}^{2}$, and $68720.99 \mathrm{~km}^{2}$, respectively, and the proportions of landocean area are $8.93 \%, 13.04 \%, 38.48 \%$, and $39.56 \%$, respectively. The suitability of natural environment plays a fundamental and decisive role in the development and construction of regional land; and the characteristics of agglomeration and dispersion are significantly different at different levels and regions. The suitability of economy and society obviously modifies that of natural environment. The introduction of marine functional zone has greatly expanded the regional land in Liaoning province, but the spatial distribution of marine functional suitability is extremely uneven. And due to the nature of marine functional zone, the space which can be directly developed and constructed is limited, while the space for protection is great. The contradiction between spatial development and ecological environment protection will be still severe for a long time.
\end{abstract}

Keywords: land spatial development; constructive land; urban-rural integration; land-ocean coordination; suitability evaluation; Liaoning province of China 